\section{Heading for harmony?}

The debate prompted by genetic manipulation developments is intensifying in Europe. Chris Sherwell reports

IN PARIS on Tuesday a committee gathered quietly for its routine monthly meeting to discuss research involving genetic manipulation using recombinant DNA technology. In Brussels last Thursday another committee lodged deep in the labyrinth of the European Commission of the EEC met to discuss the same subject. On Thursday of this week Britain's equivalent body gathers for its own regular monthly session. Within the next week a commission on genetic manipulation in the Netherlands is expected to report its long-awaited findings. And on 15 March a new and potentially crucial group within the European Science Foundation (ESF) convenes its first meeting in Strasbourg.

Plainly, the pace of developments relating to recombinant DNA research in Europe has quickened. The debate is now consuming the time of government officials, science administrators and molecular biologists in at least nine different countries and no less than five international organisations. Indeed, the aforementioned meetings are but the tip of an enormous iceberg, and if activity is symptomatic of decisiveness, the energy now being spent discussing the subject ought inevitably to produce results. For those researchers actually wanting to do the work, however, it has meant long periods of delay, uncertainty and confusion.

The debate itself stems from the development over three years ago of elegant new genetic engineering techniques, the implications of which prompted widespread concern. This spawned the growth of guidelines, specifying conditions under which various types of experiment using the techniques should be done, and the growth of committees to administer them. The result is that the issue has spread well beyond the bounds of the research community immediately involved.

In the United States for example, where the pace has been hottest, the debates freest and public involvement greatest, the National Institutes of Health (NIH) finally published a complex set of guidelines last June. Failure to broaden these voluntary controls now threatens legislation to make them stick (see box), a development which could complicate the European debate.

So far the European debate has proceeded unsensationally, mostly at $\frac{x}{0}$ the national level; progress is varied. International discussions have gone quietly ahead, both informally among individuals and formally through those bodies which have perceived a role for themseives. The chances of them continuing without rancour could diminish, however, particularly if national differences emerge strongly in certain international forums.

\section{Country catalogue}

Most European countries have in fact trodden broadly similar paths. The examples of the United States and Britain have been important, the latter adding a new word to the English vocabulary: 'geemag'. The Genetic Manipulation Advisory Group (GMAG) was established in Britain last year following recommendations from the Williams working party on genetic manipulation.

Precautions contained in the Williams guidelines, like those in the NIH guidelines, involve both physical and biological containment. The standards of physical containment are more strict under Williams, however, while biological containment receives greater emphasis in the NIH guidelines. Among other differences, the NIH guidelines provide an extensive list of experiments and appropriate containment measures; under Williams GMAG decides matters case by case. GMAG itself had early problems over trade union representation, but later began business and by this week was meeting again (see box).

At least eight other countries in Europe have sought to involve themselves in the same sort of process.

France. In France two committees are directly involved. One, called an 'ethics committee' and having under 10 members, meets spasmodically to discuss the whole subject of genetic manipulation. The other, known as the Commission de Controle, was set up in 1975 under the auspices of France's main research hody. the Delegation Ginéralc de la Recherche Scientifique et Technique (DGRSI). It has a membership of about a dozen, most of them with interests in recombinant IDNA and related research. Industry: and trade unions are not directly involved, though this could change: both are evidently prepared to abide by the Commission line.

The commission meets regularly once a month to assess the conditions under which experiments in France are to be performed. It began by using the Asilomar guidelines, the product of the Asilomar conference in California in 1975, and subsequently used the NIH guidelines. More recently it has used both the Williams and NIH guidelines.

Over a period of some 18 months it has considered some 50 applications. Less than $10^{\prime \prime}$ ", have involved the more stringent containment conditions equivalent to the P3 and P4 categories of the NIH guidelines.'The number of facilities in France which could now provide such containment is no more than a couple, and those would probably be at the P3 level.

Germany. The more fretful search for West German guidelines has produced four drafts, the latest of which was due to be distributed by the end of February, with the hope of producing a final draft by the spring. The government department involved, the Ministry of Research and Technology' (BMFT). took over after a somewhat unsuccessful start under the German Research Council (DFG) using NIH guidelines.

\author{
Sorry, for copyright \\ reasons some images \\ on this page may not \\ be available online
}


The new national guidelines are expected to follow much the same lines as the NIH and Williams precedents. There will probably be an equivalent to Britain's GMAG with mixed representation. Guidelines will be voluntary, and it is hoped that industry, for the inclusion of which there are apparently no immediate plans, will follow them. There are no national P4 facilities in Germany, and few that would qualify as P3 facilities.

Switzerland. The Swiss Academy of Medical Sciences created a standing committee known as the Commission on Experimental Genetics. Headed by Werner Arber, Professor of Microbiology at the University of Basel, it has a membership of about a dozen, consisting of experts in the field and government officials from the health and science and technology ministries. Industry is ostensibly as keen as the universities to see controls implemented, and is represented on the Commission.

The Commission decided recently to follow the NIH guidelines, but this could still change in the future. It has been agreed with government agencies that no legislation is necessary. Researchers applying to the Swiss grantgiving body (Suisse National Fonds, SNF) and supplying relevant details would go before the Commission only when the SNF is unhappy; but they will probably be invited to register their work.

Sweden. An 11-man "committee concerning research with recombinant DNA" was set up last spring under the auspices of the Natural Science Research Council (NFR), the Medical Research Council (MFR) and the Swedish Cancer Society (RmC). Its chairman, Professor Peter Reichard of the Karolinska Institute, is the appointee on the committee of the NFR, which also appoints two lay representatives-in this case two MPs. The MFR, $\mathrm{RmC}$, the Council for Forestry and Agricultural Research, the Board of Health and Welfare and the Association for the Pharmaceutical Industry each appoint one member; one member jointly represents the Academy of Sciences and the Academy of Engineering Sciences, another jointly represents the National Defence Research Institute and the Board for Technical Development; the Central Organisation for Salaried Employees appoints a representative for technical staff.

The committee will help granting agencies and government authorities to determine safety conditions for the experiments which they fund, and will probably work in the private sector as well. The committee will also advise researchers over safety precautions and help in risk classification, for which a working group has just been appointed. Researchers will be expected to submit experimental protocols to national advisory committees, which are responsible for specifying the containment measures. The containment procedures proposed are those of Williams, but experiments prohibited under the NIH guidelines, it is suggested, should not be carried out. Local safety committees would be responsible for supervising the measures.

So far the committee has received no applications and no recombinant DNA work is proceeding. The only group in Sweden which has worked in the field is at Uppsala under Professor Lennart Philipson, the MFR's appointee on the committee. His work is in abeyance, and he has yet to submit an application. The group has applied to have two new P3 laboratories built, but finance for these is not yet assured.

Denmark. Denmark has two committees. One, headed by Dr Kjeld Marcker from Aarhus, is an ad hoc committee established by the country's research council. It is examining work being done in Denmark and hopes to decide by the summer whether there ought to be a special research programme. The other is a Committee of Registration with 10 members representing research councils and industry but not trade unions. Its concern is with safety aspects, and it has been operating only a few months. The precise course it follows depends on the outcome of the first committee's work.

Holland. In January of last year, after consultation between the Royal Dutch Academy of Science and the National Health Council on the one hand, and the Ministry of Education and Science and the Ministry of Health on the other, a "Commission on Genetic Manipulation" was formed consisting of experts in the field and chaired by Professor Bootsma of Erasmus University, Rotterdam.

Its task was to compile an inventory of recombinant DNA research being done in the country and to advise laboratories on safeguards and the authorities on controls. The commission is expected to report its findings within the next two weeks, but there are differences of view about whether these should actually be published. The Dutch began by opting for the NIH guidelines but then switched to the Williams guidelines; now, however, it seems possible that national guidelines will be proposed which are more strict than either.

So far industry has not shown any public interest in the guidelines. Applications have come for six projects, from four universities. Three have

\section{Legislation for US?}

Legislation to control recombinant DNA research in the United States, a prospect which clearly concerns many scientists, is now considered inevitable. Bills have already been introduced into Congress, and in the next few weeks a committee consisting of officials from a number of federal agencies is expected to draft legislation to be submitted to Congress with the backing of the Carter Administration.

The Administration is reluctantly being pushed into drafting its own bill because if it doesn't, it will invite the prospect of harsher legislation and inconsistent local controls on recombinant DNA research. At present, the only formal controls on recombinant DNA research in the United States are guidelines issued last June by the National Institutes of Health (NIH), but they apply only to research supported by the federal government, and they are not backed by any enforcement or monitoring mechanism. Industry is not bound by any regulations.

Those apparent weaknesses in the present approach have prompted several state and local governments to consider adopting their own regulations on recombinant DNA research, and the fact that industrial research is not regulated at all has caused considerable public concern. Consequently, an inter-agency committee was established late last year under the chairmanship of NIH Director Donald Fredrickson to examine ways to extend the NIH guidelines to cover all recombinant DNA research in the United States. The committee has tentatively decided that no existing federal law can be used to extend and enforce the guidelines, and that new legislation is required.

That tentative conclusion was conveyed by Fredrickson last week to a group of prominent scientists and university administrators which met at NIH. Though Fredrickson repeatedly noted that no decision has been reached on the substance of the Administration's bill, it would almost certainly be designed simply to turn the NIH guidelines into enforceable regulations. It is also likely to include a clause preempting state and local regulations in an effort to ensure that regulations are uniform throughout the L'nuted States. It is not clear which agency would do the enforcing-clearly NIH wouldn't want to be in the position of supporting and regulating the research-but the likelihood is that the Center for Disease Control would be given the responsibility.

Colin Norman

come from the University of Amsterdam, and one from the Free University of Amsterdam, the University of I.eiden and the University of Groningen.

Israel. A committee of the Israel Academy of Sciences and Humanities, chaired by Professor Leo Sachs of the Weizmann Institute, has recommended the establishment of a national safety committec for recombinant DNA research and of special safety committees at universities and research centres. 
The local committees would recommend appropriate safety precautions for every research proposal and then pass the matter to the national body, which has the final word.

The Academy decided that Israeli researchers would in general follow the NIH guidelines but would take into consideration recommendations from other bodies.

\section{International catalogue}

For Europe's researchers, worry as well as confusion is the product of the growing involvement of an increasing number of international bodies. But the important issue-whether or not there should be harmonisation of guidelines-already seems settled. There were benefits in allowing each country to follow its own path and arrive at its own conclusions, but different precautions in different countries threatened to encourage a concentration of researchers, so harmonisation looked preferable.

Moreover, with the subject a matter for public debate, there was the possibility that if one country applied more stringent controls than another, the difference itself could become an issue. Harmonisation could pose problems, though, if US researchers are faced with legally enforced regulations and there is public pressure for similar regulations in Europe. Creating a disinterested peer group competent to judge colleagues' work could be difficult enough without the added (if necessary) complication of drafting and enforcing legislation.

The case for harmonisation does not, however, solve the problem of which body has the authority to encourage the move towards it. A look at the organisations involved reveals the difficulty.

The World Health Organisation (WHO). The WHO has two bodies actively involved, the WHO Special Programme on Safety Measures in Microbiology and the WHO Environmental Programme. Being global and not confined to Europe, and concerned with the public heaith and safety aspects of the research, the WHO interest is peripheral as yet, although it has begun consultations, with, for example, Professor S. W. Glover, chairman of the International Microbial Genetics Commission, which has a genetic engineering sub-group.

The International Council of Scientific
Unions (ICSU). ICSU has recently created a sub-committee known as COGENE, headed by the US microbiologist Bill Whelan. Its first official meeting is in Paris at the end of May. Because it too is part of a global agency, and because it represents international commissions in various disciplines more than national councils, ICSU can acquire an important role outside North America and Western Europe.

It can, for example, involve the East European countries and also the USSR, which is apparently keen to participate in the research under agreed guidelines-the USSR has a committee under Professor Bayev which hopes to produce its own guidelines by the middle of the year. ICSU can also involve important Third World countries, such as India and Nigeria, which cannot be prevented from pursuing the research but which might participate in any programme organised by ICSU on their behalf to help ensure that they take the necessary precautions.

The European Molecular Biology Organisation (EMBO). EMBO is based at Heidelberg, where a P4 facility for international use is under construction.

\section{Britain's GMAG gets going}

BRITAIN's Genetic Manipulation Advisory Group (GMAG) has already given outline approval to more than half a dozen experiments, including one that requires the highest level of containment. For the present, however, the only place where such an experiment can be carried out is Porton, a Ministry of Defence establishment whose future is under scrutiny.

GMAG meets monthly to consider proposals for genetic manipulation experiments which, while awaiting a legal definition, are taken to refer to those in which restriction enzyme fragments of nucleic acids are recombined with the genomes of other organisms in which they are capable of propagation. GMAG's chairman is Sir Gordon Wolstenholme; it has 19 members, of whom only three have a direct interest in recombinant DNA research. Most of the others are biological scientists, but there are four union representatives and two nonscientific academics.

It is GMAG's task to consider any proposals and to state its objections, if any. Proposals (25 copies) are submitted on a formidable form on which ful details of the protocol, personnel and facilities have to be provided along with information rcgarding local safety committees, biological safety officers, medical officers and health monitoring schemes. Proposed experiments fall into four categories. depending on the associated hazards. It is up to the proposers to categorise their own experiments but up to GMAG to ascertain whether the relevant requirements are satisfied.

In the case of the two categories (III and IV) that represent the greatest hazards, GMAG has to carry out a site inspection of the facilities. This they have already done for the category III facility at the MRC Mammalian Genome Unit in Edinburgh. Professor Peter Walker of that unit expresses himself well satisfied with the visit and its outcome which, pending attention to a few minor problems, should give him the first approved category III facility in Britain. Site visits have also been requested for a proposed category III laboratory at Imperial College and for the Microbiological Research Establishment at Porton. It is on Porton that British shortterm hopes for a category IV facility hang-though for now on some rather delicate strings. Porton is the property of the Ministry of Defence and has been the laboratory in which much of Britain's microbiological warfare research has been carried out. As such it has long been unloved by many academics. Now it is also unloved by the Ministry, which recently announced that it no longer has a use for the microbiological laboratories. Since December their future has been uncertain and is now the subject of a confidential report prepared by the Central Policy Review Staff for the Cabinet (see Britain, page 9). A decision is thought to be imminent.

There are bound to be problems if the decision leaves the laboratories under the control of the Ministry of Defence. If that happened, it is known that a faction of GMAG. led by some of the trade union representatives, would be strongly opposed to the usc of Porton's facilities for civil genetic manipulation. That could prevent the go-ahead of any category IV experiments, including the one that has already been given outline approval. until an alternative category IV laboratory could be found. At the moment none are planned but it would not be too far-fetched to suppose that the proposed category III facility currently being completed at the Beatson Institute. Glasgow, could be upgraded if required.

It is Scottish laboratories that have so far taken the lead in applying to GMAG, with their English counterparts being distinctly slow off the mark. Of the expected initial batch of 40-50 applications less than 15 had reached GMAG by its third meeting last month and at least eight of those were from north of the border, mainly from Professor Walker's laboratory.

GMAG has in fact expressed surprise at the paucity of applications and has reminded those concerned that they would be foolish not to present their proposals to the group. At present application to GMAG is voluntary although the UK Health and Safety Commission (HSC) is redrafting its controversial regulations that would make notification compulsory. The original proposals were strongly criticised for being far too wide-ranging, especially as existing health and safety regulations already cover the laboratory hazards of genetic manipulation in the general sense.

The Research Councils have themselves warned of their intention of withdrawing funding of any rogue manipulators. Only industry would therefore be immune from financial sanctions, but the two most interested pharmaceutical companies have already made their intentions clear by submitting proposals to GMAG.

Peter Newmark 
It was the first international European body to become involved in guidelines for recombinant DNA research, and has a Standing Advisory Committee on Recombinant DNA chaired by Professor Charles Weissmann. This was set up in January 1976 and held its first meeting in London the following month to discuss whether it was worth elaborating guidelines, other than those available, for Europe as a whole.

At its second meeting, in London last September, the committee compared the NIH and Williams guidelines. It suggested the establishment of national advisory groups to specify containment measures for each experiment on the basis of a detailed protocol submitted to it. The committee specifically recommended against the idea of using some combination of the procedures from the two sets of guidelines. And it advised that experiments forbidden under the NIH guidelines not be carried out.

The European Science Foundation (ESF). Established in November 1974, the ESF is made up of 45 national research councils and academies from 18 European countries and aims to create a close-knit community of science and research in Europe. Sweden quickly suggested to the founding committee that it should consider the whole question of genetic manipulation, including its social, legal and ethical aspects. With the EMBO committee able only to provide advice on request, and then only about scientific and technical aspects, the ESF decided in October 1975 to broaden a preparatory working party into an ad hoc committee on Recombinant DNA which could propose through ESF members whether and what action should be taken at European level.

The committee met three times in 1976 under the chairmanship of Professor Povl Riis of Denmark; members included molecular biologists, physicians and lawyers. Their brief was broad, and they concluded that the recommendations and code of practice of the Williams report should be adopted as the guidelines for recombinant DNA research in Europe. They also recommended that national registries of research should be established and that laboratories should be legally obliged to declare their work to it; laboratories would adhere to agreed guidelines voluntarily, however, and supervision and monitoring would be a national responsibility. National variations, it suggested, should be minimised.

The ESF has now created a new committee made up of representatives of the geemags of its members with the aim of proposing guidelines for Europe. This European Committee on Recombinant DNA will meet for the first time in Strasbourg on 15 March. It will note differences in the practices of various countries and consider prescribing measures for the future.

The European Commission. The European Commission, which has a dual role in the EEC of both initiating and implementing Community legislation, finally jumped into the fray in January. Spotting the opportunity provided by a potential need for Community-wide legislation and harmonisation, Directorate General XII (Research, Science and Education), headed by Dr Gunter Schuster, called geemag heads to Brussels on 21 January for "informal consultations". This offended some sensibilities, not least because Dr Schuster was seeing members of the new ESF committee on which he is himself the EEC's representative.

The Commission is apparently contemplating a directive, the device by which it can request member states to modify and harmonise their legislation. In the case of recombinant DNA research this might involve asking the Nine to ensure that they take the same precautions, but not interfering with the operations of individual gcemags. At the January meeting there was no stern objection to the idea, provided a directive was not too specific or detailed.

The worry is not chiefly about Commission interference, although its record in science is less adequate that it might be. Most people recognise that it possesses the authority both to hasten the necessary harmonisation and to incorporate research done in the private sector a common framework. The worry for the moment is related more to the style and timing of the Commission's involvement, which could be self-defeating if it breeds resentment among researchers.

The outcome of the January meeting was presented last week at a meeting in Brussels of the Medical Research Committee, a sub-committee of CREST, the Commission's Scientific and Technical Research Committee. According to the office of the director of the biology programme, the meeting reached no firm conclusions and is due to meet again only in June. That may mean that EEC invlovement will remain peripheral for a while yet. If so, the immediate burden of recommending a path for recombinant DNA research in Europe now lies with the ESF.

\section{From Carter via Ford}

Colin Norman reports from Washington on President Carter's proposed budget changes

AFTER three weeks of frantically sifting through the massive set of budget proposals which President Ford left behind, President Carter last week sent Congress a raft of major and minor amendments. Designed to implement some of Carter's more prominent election promises and political priorities, the proposed budget revisions would undo some of the Ford Administration's parsimony toward health, welfare and housing programmes and add about $\$ 19,400$ million to previous estimates of government spending in the 1978 fiscal year (which begins on 1 October, 1977).

As far as science and technology are concerned, the only areas which figured prominently in campaign rhetoric were energy and military research and development, and consequently they are the only areas greatly affected by Carter's proposed budget revisions. Outside those two fields, Carter has proposed a small addition to Ford's budget for NASA for studies of possible follow-up missions to the Mars Viking Lander project, and a $\$ 5$ million increase in the budget of National Institutes of Health (NIH) for research on childhood diseases. Otherwise, the relatively large budget increases for basic research, earthquake prediction and agricultura, research proposed by President Ford have been left untouched.

The proposed revisions to the budget for energy research and development are another matter. Acting on the advice of James Schlesinger, his energy adviser, Carter has scaled down Ford's budget proposals for three longterm energy programmes-the breeder reactor, development of large solar power plants and thermonuclear fusion -and redirected some of the funds towards efforts likely to produce shortterm results. The proposals signal a major shift in priorities and indicate that the new Administration is prepared to play a more aggressive role than its predecessor in pushing new technologies, such as solar heaters and electrically powered automobiles. into the market-place. The budget pro- 